Pesq. Vet. Bras. 36(5):357-362, maio 2016 DOI: $10.1590 /$ S0100-736X2016000500001

\title{
First phylogenetic analysis of Avipoxvirus (APV) in Brazil ${ }^{1}$
}

\author{
Hiran C. Kunert-Filho ${ }^{2 *}$, Samuel P. Cibulski², Fabrine Finkler ${ }^{2}$, Tiela T. Grassotti², \\ Fátima R.F. Jaenisch ${ }^{3}$, Kelly C.T. de Brito ${ }^{2}$, Daiane Carvalho², Maristela Lovato ${ }^{4}$ \\ and Benito G. de Brito ${ }^{2}$
}

\begin{abstract}
Kunert-Filho H.C., Cibulski S.P., Finkler F., Grassotti T.T., Jaenisch F.R.F., Brito K.C.T., Carvalho D., Lovato M. \& Brito B.G. 2016. First phylogenetic analysis of Avipoxvirus (APV) in Brazil. Pesquisa Veterinária Brasileira 36(5):357-362. Laboratório de Saúde das Aves e Inovação Tecnológica, Instituto de Pesquisas Veterinárias Desidério Finamor, FEPAGRO Saúde Animal, Estrada do Conde 6000, Eldorado do Sul, RS 92990-000, Brazil. E-mail: hiran_veterinario@hotmail.com

This study represents the first phylogenetic analysis of avian poxvirus recovered from turkeys in Brazil. The clinical disorders related to fowlpox herein described occurred in a turkey housing system. The birds displaying characteristic pox lesions which were observed on the neck, eyelids and beak of the turkeys. Four affected turkeys were randomly chosen, euthanized and necropsied. Tissues samples were submitted for histopathological analysis and total DNA was further extracted, amplified by conventional PCR, sequenced and phylogenetically analyzed. Avian poxviruses specific PCR was performed based on $P 4 b$ core protein gene sequence. The histological analysis revealed dermal inflammatory process, granulation tissue, hyperplasia of epithelial cells and inclusion bodies. The $P 4 b$ gene was detected in all samples. Sequencing revealed a $100 \%$ nucleotide and amino acid sequence identity among the samples, and the sequences were deposited in GenBank ${ }^{\circledR}$. The four Avian poxviruses fragments sequenced in this study clustered along the A1 clade of avipoxviruses, and were classified as Avipoxvirus (APV). Additional studies, such as virus isolation, PCR and sequencing includinga large number of specimens from the Brazilian turkey production must be conducted due to the hazardous risk that poxvirus infections may cause to the Brazilian poultry production scenario, given that Brazil's turkey production attracts attention due to its economic importance worldwide. Our findings point to the need to identify the prevalence of APV in Brazilian turkey production, to perform risk assessment studies and continued surveillance of APV infections in both wild and commercial avian species.
\end{abstract}

INDEX TERMS: Turkey, Poxviridae, Avipoxvirus, APV, PCR, phylogenetic analysis.

RESUMO.- [Primeira análise filogenética de Avipoxvirus (APV) no Brasil.] Este trabalho representa a primeira análise filogenética de Poxvirus aviário detectado em perus no

\footnotetext{
${ }^{1}$ Received on October 22, 2015.

Accepted for publication on February 4, 2016.

${ }^{2}$ Laboratório de Saúde das Aves \& Inovação Tecnológica (LSAIT), Instituto de Pesquisas Veterinárias Desidério Finamor (IPVDF), FEPAGRO Saúde Animal, Estrada do Conde 6000, Eldorado do Sul, RS 92990-000, Brazil. *Corresponding author: hiran_veterinario@hotmail.com

${ }^{3}$ Laboratório de Patologia, Embrapa Suínos e Aves, Rodovia BR-153 Km 10, Cx. Postal 21, Concórdia, SC 89700-000, Brazil.

${ }^{4}$ Laboratório Central de Diagnóstico de Patologias Aviárias (LCDPA), Departamento de Medicina Veterinária Preventiva (DMVP), Centro de Ciências Rurais (CCR), Universidade Federal de Santa Maria (UFSM), Av. Roraima 1000, Santa Maria, RS 97105-900, Brazil.
}

Brasil. Os distúrbios clínicos relacionados com bouba aviária aqui descritos ocorreram em um sistema de alojamento de perus. As aves apresentaram lesões características de varíola observadas no pescoço, pálpebras e bico das aves. Quatro perus com sinais característicos foram escolhidos aleatoriamente, sacrificados e submetidos à autópsia. Amostras de tecido foram submetidas à análise histopatológica e o DNA total foi extraído, amplificado por PCR convencional e os amplicons foram sequenciados e analisados filogeneticamente. A PCR específica para Poxvírus aviário foi realizada com base na seqüência do gene da proteína do núcleo $P 4 b$. A análise histológica revelou um processo inflamatório dérmico, tecido de granulação, hiperplasia de células epiteliais e corpúsculos de inclusão. 0 gene $P 4 b$ foi 
detectado em todas as amostras. 0 sequenciamento revelou uma identidade entre nucleotídeos e aminoácido de $100 \%$ entre as amostras e as sequências foram depositadas no GenBank ${ }^{\circledR}$. Os quatro fragmentos de poxvírus aviário sequenciado neste estudo foram agrupados no clado A1 de avipoxvirus e foram classificados como Avipoxvirus (APV). Estudos adicionais, como isolamento viral, PCR e sequenciamento, incluindo um grande número de perus da produção brasileira devem ser conduzidos devido ao grave risco que a infecção por poxvírus pode causar ao cenário de produção avícola brasileira, tendo em vista que a produção brasileira de perus atrai atenção devido a sua importância mundial. Nossos resultados apontam para a necessidade de identificar a prevalência da APV na produção de peru no Brasil, para realizar estudos de avaliação de risco e continuada monitoração de infecções por APV nas espécies de aves comerciais e silvestres.

TERMOS DE INDEXAÇÃO: Peru, Poxviridae, Avipoxvirus, APV, PCR, análise filogenética.

\section{INTRODUCTION}

Avian poxviruses cause a common viral disease in bird species. It is worldwide distributed, affecting at least $3 \%$ of 232 species of birds (Bolte et al. 1999, Tripathy et al. 2000, Kim et al. 2003, Godoy et al. 2013). APV may manifest in two different ways: lesions on the skin, commonly named as cutaneous form, and lesions in the mouth, pharynx, larynx, esophagus and trachea, called diphtheritic form. These two forms may occur simultaneously (Biswas et al. 2011). When Avipoxvirus (APV) affects poultry production, it can lead to decreased egg production, reduced growth, and increased mortality. In canaries, APV causes severe pulmonary damage, leading to extremely high mortality rates (Manarolla et al. 2010).

Viruses belonging to the APV family are large, oval, brick-shaped, and enveloped. Double-stranded DNA ranging from 130 to $375 \mathrm{~kb}$ in linear configuration is the main characteristic of the members of this family (Bolte et al. 1999, Manarolla et al. 2010). APV DNA usually presents a low (about 30 to 40\%) GC-content (Bolte et al. 1999), encoding about 150 genes (Lefkowitz et al. 2006). Avian cell tissue cultures (e.g., chicken embryo fibroblasts, chicken embryo dermis and kidney cells, and duck embryo fibroblast) and chorioallantoic membrane (CAM) of embryonated eggs are the tissues of choice for APV isolation, due to its easily replication. Nonetheless, turkeys isolates may fail to grow in these cell lines, even after repeated passages (Tripathy \& Reed 2013). According to Jarmin et al. (2006), APV replicates within the cytoplasm of the cells that they infect, causing type A cytoplasmic inclusions (Tripathy \& Reed 2013).

Chordopoxvirinae (ChPV) and Entomopoxvirinae (EnPV) are two subfamilies within Poxviridae family. The first one infects vertebrates, and the second one infects insects $\mathrm{CHu}$ ghes et al. 2010, Manarolla et al. 2010). The subfamily ChPV comprises eight genera: Avipoxvirus, Molluscipoxvirus, Orthopoxvirus, Capripoxvirus, Suipoxvirus, Leporipoxvirus, Yatapoxvirus and Parapoxvirus; whereas four genera are found in EnPV subfamily: Alphaentomopoxvirus, Betaento- mopoxvirus, Gammaentomopoxvirus and a not assingned one (www.ictvonline.org/virusTaxonomy.asp). Avipoxvirus is the only genus capable of infecting birds (Gubser et al. 2004).

To date, ten species have been described as belonging to the genus Avipoxvirus: Canarypox virus, Fowlpox virus, Juncopox virus, Mynahpox virus, Pigeonpox virus, Psittacinepox virus, Quailpox virus, Sparrowpox virus, Starlingpox virus and Turkeypox virus. There are three other species as additional attempt by the International Commitee on Taxonomy of Viruses: Peacockpox virus, Penguinpox virus, Crowpox virus (www.ictvonline.org/virusTaxonomy.asp). The prototype of the APV family is Fowlpox virus (FWPV), which causes lesions on the skin and in the upper respiratory tract (Tadese et al. 2008).

Poxvirus infections cause cutaneous and internal lesions and may affect chickens and turkeys (Tripathy \& Reed 2013). Microscopically, the skin lesions are characterized by severe hypertrophy and hyperplasia of epidermal cell, many of which undergoing ballooning degeneration and often containing intracytoplasmic eosinophilic inclusion bodies called Bollinger bodies. These inclusion bodies are pathognomonic for Avian poxvirus infection (Fletcher 2008).

Histopathological examination is considered the major method for APV diagnosis, but other techniques, such as cell tissue cultures, virus isolation in CAM of embryonated chicken eggs, serologic methods and electron microscopy (Tripathy \& Reed 2013) are available to isolate or detect the virus. To date, the most sensitive techniques include several molecular approaches (Manarolla et al. 2010). Hence, the amplification of a 578-base pair (bp) region of $P 4 b$, a highly conserved gene of $\mathrm{APV}$, is commonly used to diagnose APV infections, which is highly conserved amongst all poxviruses (Binns et al. 1989). The $P 4 b$ gene has already been reported in other phylogenetic studies of APV to distinguish between clades A, B, C, A1-4 and B1-2 (Lüschow et al. 2004, Weli et al. 2004, Jarmin et al. 2006). In addition, conventional and real time PCR techniques provide results more rapidly than virus isolation.

The aim was to characterize Avian poxvirus isolates from turkeys in Southern Brazil. For this purpose we used histopathological analysis, PCR, and phylogenetic analysis.

\section{MATERIALS AND METHODS}

Sample collection. In this survey, about 80 out of 120 140-days-old turkeys (Meleagris gallopavo) housed in the Instituto de Pesquisas Veterinárias Desidério Finamor (IPVDF), Eldorado do Sul, Rio Grande do Sul State, Brazil, demonstrated clinical signs consistent with Pox. The characteristic lesions were observed on the neck, eyelids and beak of the turkeys (Fig.1). The apparently diseased birds displayed roughened feathers and stunted growth. Most affected turkeys died suddenly, and four animals, displaying the symptoms described above were randomly chosen and necropsied for tissue collection in order to carry out histopathology and molecular diagnosis. All animals were housed and fed in accordance with procedures required by animal welfare and registered under protocol number 11/2011 from IPVDF. The turkeys were euthanized according to established procedures.

Histopathology. Tissue samples from necropsied turkeys were fixed with $10 \%$ buffered formalin and taken to the Histopa- 


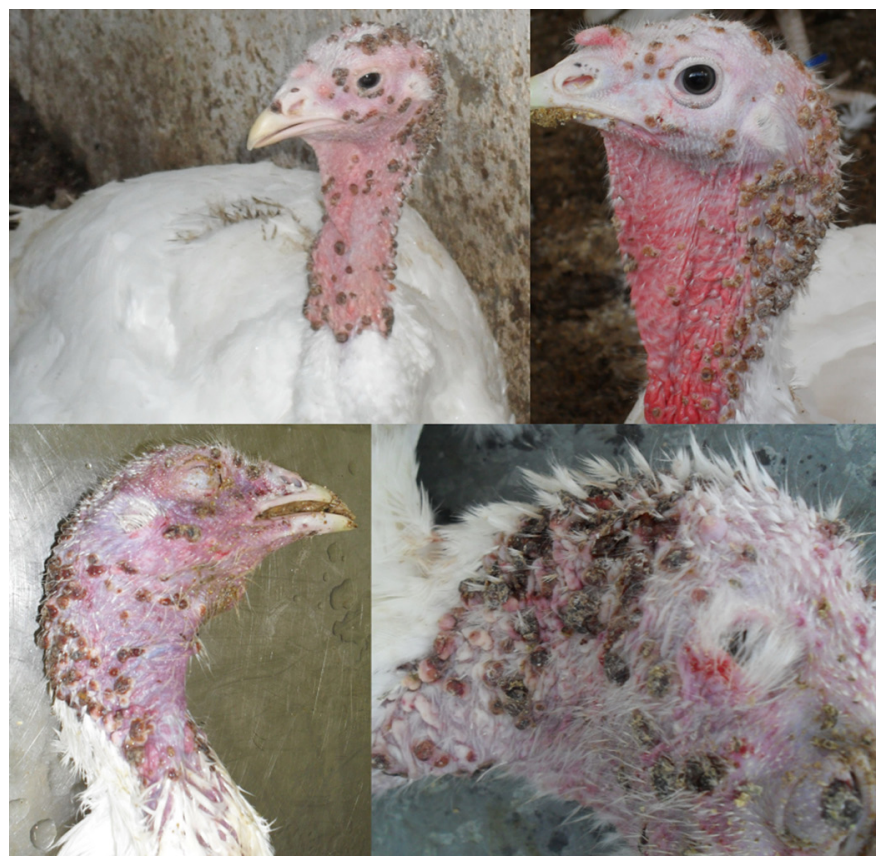

Fig.1. Lesions and scabs on the skin of affected turkeys of this study. The cutaneous form is characterized by the presence of nodular proliferative lesion in the featherless parts of the body (comb, wattles, ear lobes, eyes, and sometimes the feet).

thology Laboratory for processing and histological analysis according to the technique of Luna (1968). Tissue sections were cut, dehydrated, cleared, embedded with paraffin, laminated at $5 \mu \mathrm{m}$ and stained with haematoxylin and eosin for histological examination by optical microscopy.

DNA extraction, PCR amplification and sequencing. The DNA extraction was carried out using $25 \mathrm{mg}$ of the skin, trachea and pulmonary lesions from individuals showing clinical signs, as well as from $1 \mathrm{~mL}$ of the lyophilized vaccine using phenol (Amres$\mathrm{Co}^{\circledR}$ ) used as a positive control according to Sambrook \& Russel (2001). Tissues were submitted to digestion by proteinase K at 56 ${ }^{\circ} \mathrm{C}$ for 1 hour. The DNA was quantified fluorometrically, and DNA samples were stored at $-80^{\circ} \mathrm{C}$ until analysis.

APV-specific and FPV140 PCRs were performed according to Manarolla et al. (2010). The APV specific PCR was performed using a primer pair described by Huw Lee \& Hwa Lee (1997) based on $P 4 b$ sequence of FPV virus strain HP444. FPV specific PCR was performed using a primer pair described by Jarmin et al. (2006), with a forward primer with slight modifications described by Manarolla et al. (2010). APV and FPV amplifications were performed as described by Manarolla et al. (2010), except that the final extension of APV specific PCR was $10 \mathrm{~min}$ at $72^{\circ} \mathrm{C}$.

PCR products were separated by $2 \%$ (for $P 4 b$ ) and $1.2 \%$ (for FPV140) agarose gel electrophoresis, and stained with ethidium bromide. PCR products of $P 4 b$ gene with the specific size were submitted to Sanger sequencing. The sequences were deposited in GenBank ${ }^{\circledR}$ database under accession numbers: KM396387, KM396388, KM396389 and KM396390.

To assess the phylogenetic clustering and relationship among the different APV, the P4b sequences were aligned with APV sequences available in GenBank ${ }^{\circledR}$ (clustalW, Thompson et al. 1994), using the neighbour-joining method according to the Jukes \& Cantor model. The out-group used for P4b gene was Molluscum contagiosum virus (MOCV). Bootstrap values were determined by 1,000 replicates to assess the confidence level of each branch pattern. All phylogenetic analyzes were run by MEGA 6.0.6 (Tamura et al. 2013).

\section{RESULTS}

\section{Histopathology.}

The histological analysis of the cutaneous lesions revealed inflammatory process in the dermis, granulation tissue, and hyperplasia of epithelial cells. In some fragments, it was possible to detect the pathognomonic lesions of APV infection (Fig.2).

\section{PCR and sequencing.}

All four clinical cases sampled were positive for the APV-specific PCR (Fig.3). The size of the amplicon of P4b gene (about $580 \mathrm{bp}$, including primers) was in agreement with the size of the published nucleotide sequences (Fig.4).

A phylogenetic tree was constructed (Fig.5) and the sequences showed a 100\% nucleotide and amino acid sequence identity, clustering along clade A1. The identity between these sequences and known APV viruses ranged

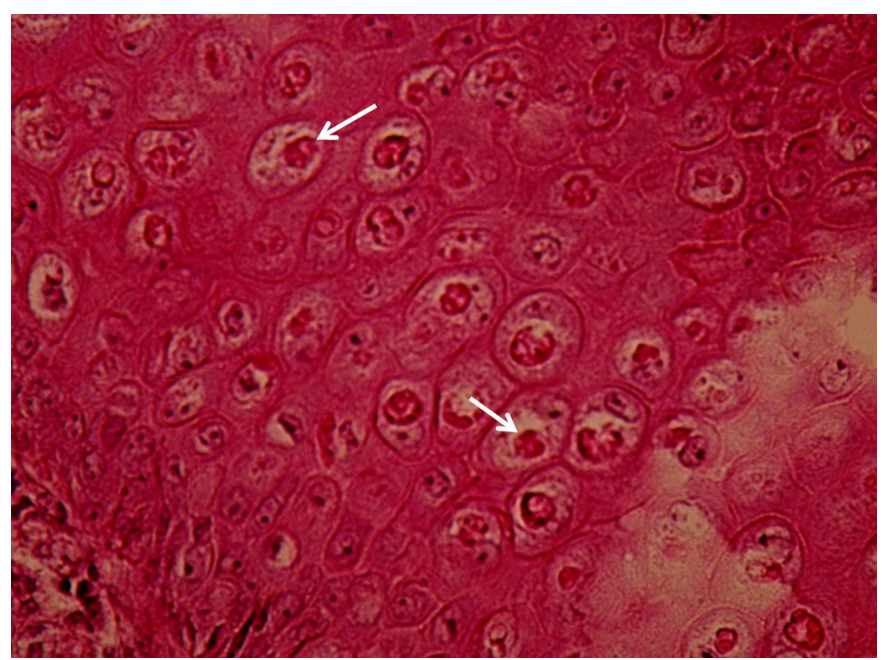

Fig.2. Epidermal cells associated with intracytoplasmic inclusions of poxvirus. The arrows indicate the presence of intracytoplasmic eosinophilic inclusion bodies named Bollinger bodies.

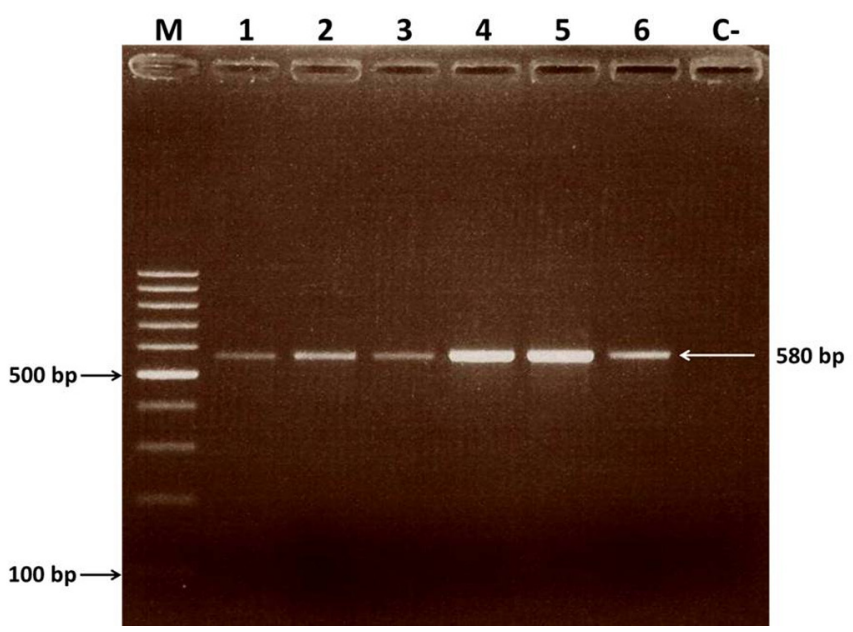

Fig.3. PCR amplicons of the $P 4 b$ gene of turkey avianpoxvirus from this study. Lane M, DNA ladder 100 bp (Ludwig Biotec $^{\circledR}$ ); 1, Ave 5 (KM396387); 2, Ave 5M (KM396388); 3, Ave 10 (KM396389); 4 and 5, Positive control (Vaccine); 6, Ave 20 (KM396390) and C-, Negative control. 


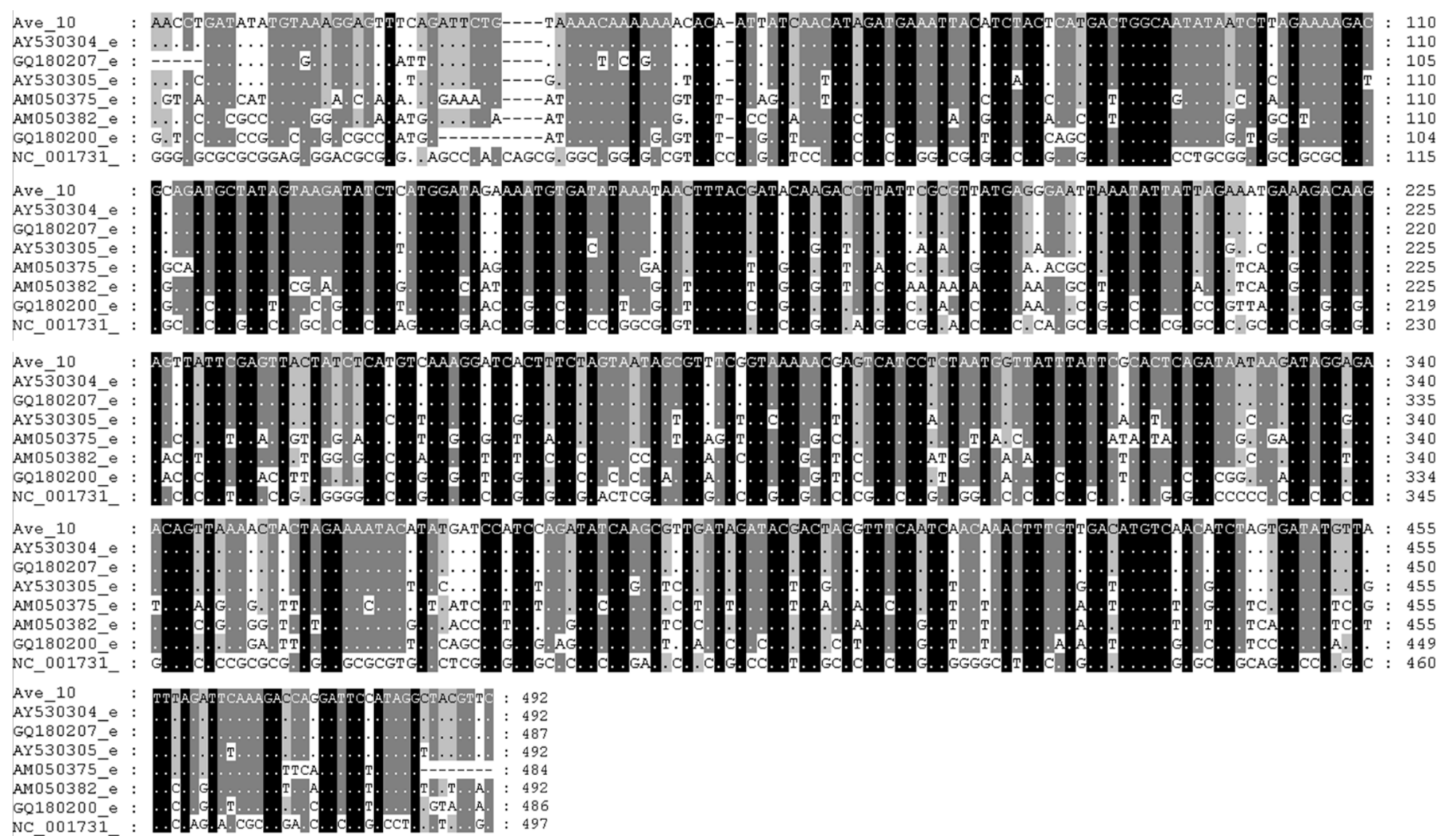

Fig.4. Alignment of the $P 4 b$ gene of turkey avianpoxvirus from Southern Brazil, and $P 4 b$ published nucleotide sequences indicating that the nucleotides are similar to those isolated in this study. Ave 10 (KM396389) Turkey (this study). AY530304 a Turkey from Germany. GQ180207 a Pheasant from Italy. AY530305 an Ostrich, probably from United Kingdom. AM050375 a Canary, probably from the United Kingdom. AM050382 a Macaw from United Kingdom. GQ180200 a Quail from Italy. NC_001731 Molluscum contagiosum virus subtype 1 .

from $91 \%$ to $99 \%$ in clade $\mathrm{A} 2,76 \%$ to $78 \%$ in clade $\mathrm{B}$, and $75 \%$ in clade $\mathrm{C}$. The Quail strain, not allocated in any cluster, displayed $75 \%$ identity with our samples. The MOCV subtype 1 (NC001731) was included as an out-group.

PCR for amplification of FPV140 was also carried out, and FPV140 genome was detected in all four samples. Amplicons from samples KM396387, KM396388, KM396389 and KM396390 had 2400 bp length whereas amplicons from fowlpox vaccine were $1800 \mathrm{bp}$ in size (data not shown).

\section{DISCUSSION}

Brazil is the second largest exporter and the third largest producer of turkeys in the world and its production attracts attention due to its economic importance. Many advances have been made concerning sanitary management, promoting a high health status to the turkey production.

Avian poxviruses can be isolated from many others avian species besides turkeys, such as wild birds, pet birds, poultry and laying hens. Both broilers and laying hens are usually vaccinated against fowlpox in the summer, because of the proliferation of the major vector of APV, Culex spp, increasing during this season.

In this study, turkeys that displayed symptoms were not vaccinated for fowlpox. This suggests that some APV strains might have been introduced in the flock and spread among the turkeys causing the classical signs of fowlpox. These findings demonstrate that the turkeys can be infec- ted by poxviruses, and the molecular techniques offer opportunities for the detection of this DNA virus.

Molecular techniques, such as PCR and sequencing, enabled us to classify the samples as Avipoxvirus. It must be highlighted the importance of this phylogenetic study as it is the first phylogenetic study of APV from turkeys in Brazil. Other studies conducted in Brazil were based on clinical diagnosis, histopathology, virus isolation and an optimized nested PCR for APV diagnosis. Regarding turkeys, there is only one report about the presence of pox virus in this species referring the treatment of animals using $\mathrm{d} i$-(4-amidinophenyl)-triazine-(N-1,3)-diaceturate (Lamounier et al. 1966). Back et al. (1995) reports an outbreak of Fowlpox in broiler chickens and the diagnostic was performed by histopathology and virus isolation. Fallavena et al. (2002) reports the presence of FWPV in Dermal Squamous Cell Carcinoma (DSCC) also in broiler chickens using a nested PCR. Silva et al. (2009) reports the presence of Fowlpox in backyard chickens by clinical signs and confirming the diagnosis by histopathology. Vargas et al. (2011) reported an infection by Avian poxvirus in barn owl, and Pereira et al. (2014) reported a cutaneous tumor-like lesions associated with infection by APV in a Dendrocygna autumnalis. Both studies confirmed the diagnosis by clinical signs as well as by histopathology. To our knowledge this is the first phylogenetic analysis of APV in turkeys in Brazil.

All four APV fragments sequenced in this work belonged 


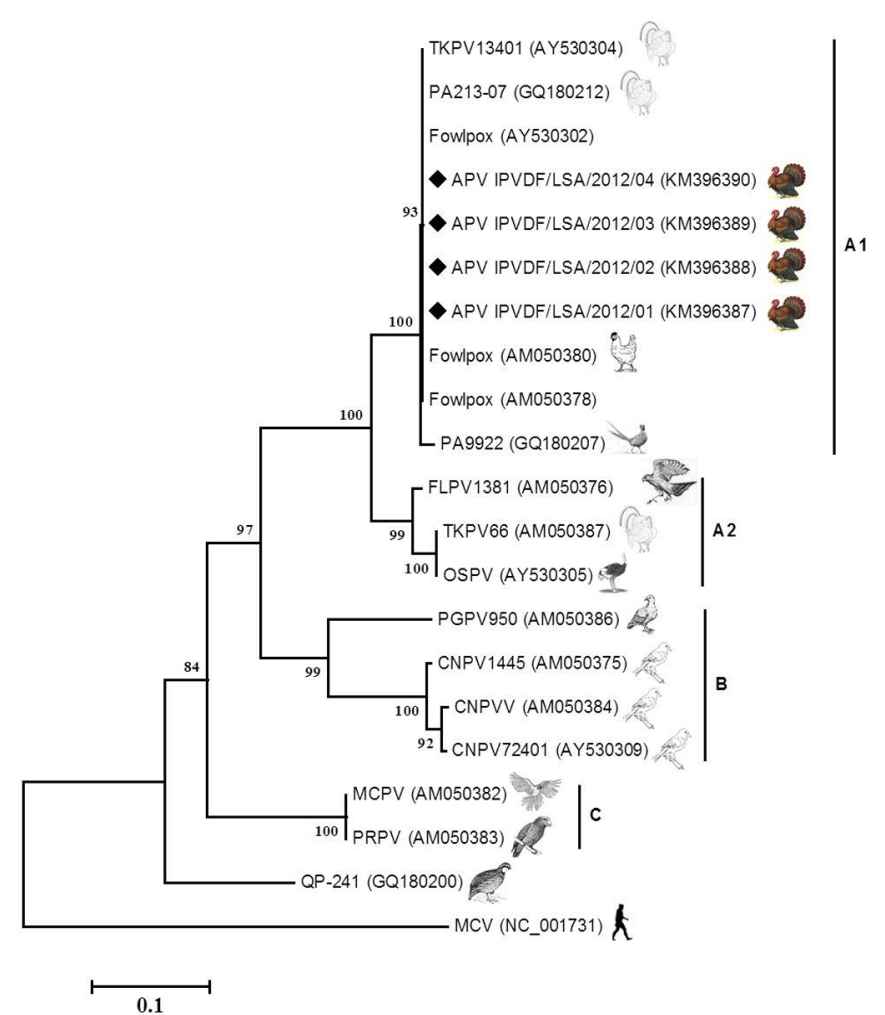

Fig.5. Derived phylogenetic tree of nucleotide sequence of the $P 4 b$ core protein gene of APV isolated in this study [marked with diamond $(\bullet)$ ]. Neighbour-joining method was utilized to perform the phylogenetic tree, and calculated according to Jukes and Cantor model. The outgroup used for $P 4 b$ gene was Molluscum contagiosum virus (MOCV). Bootstrap values were determined by 1,000 resampling to assess the confidence level of each branch pattern. All phylogenetic analysis was calculated by MEGA version 6.0.6 (Tamura et al. 2013). APV clades A-C are highlighted.

to the A1 clade of avipoxviruses and were identical to each other, being classified as Avipoxvirus. The identity among our sequences obtained in this study may be due to the fact that they originated from the same outbreak. Our isolates also presented high similarity $(100 \%)$ in comparison to other previously characterized strains belonging to A1 clade (strains AY530304 and GQ180212 (turkeys), AY530303 (FWPV HP-B vaccine), AM050380 and AM050378 (chickens), and GQ180207 (pheasant), and with the attenuated fowlpox vaccine (Difotvax ${ }^{\circledR}$ MERIAL $^{\circledR}$ - sequencing not shown) used by the Brazilian poultry industry. The closest turkeys avipoxvirus $4 b$ virion core protein sequences found in GenBank ${ }^{\circledR}$, in the subclade A1, were from Italy (GQ180212) and Germany (AY530304), which were identical to our samples on the level of nucleotide and amino acid sequence.

The turkey APV DNA sequenced here appears to be closely related to a falcon APV (AM050376) isolate from United Arab Emirates (Jarmin et al. 2006), a turkey (AM050387) isolate from United Kingdon (Jarmin et al. 2006) and an ostrich (AY530305) without any isolation location defined (Lüschow et al. 2004), and all of them belonging to A2 clade. The closest turkey APV sequence found in A2 clade was from Italy (GQ180212), and varied 9\% on the amino acid level.

The sequences within cluster B, AM050386, AM050375, AM050384, AY530309, share nucleotide and amino acid identities of $76 \%, 78 \%, 76 \%$ and $76 \%$, respectively. In the cluster C, samples AM050382 and AM050383 share 76\% of identity. All these samples are from United Kingdom. The small difference between the sequences recovered here and those from Europe and United Arab Emirates may be due to the high conservation of APV DNA. This suggests that some APV strains might have been introduced to Brazil from Europe by the importation of European/American poultry lineages to improve the genetic quality of poultry in Brazil. This also suggests the possible introduction of APV strains from overseas with the introduction of exotic bird species such as passerines (Ha et al. 2011). Previous work showed that an APV isolate from a free-ranging bird presented a genetic similarity with FWPV and turkeypox virus (Lüschow et al. 2004; Ha et al. 2011).

The results of this work confirm that turkeys of Brazil are susceptible to APV infection. The diseased specimens analyzed in this work were positive for APV DNA. Avipoxvirus infection is not considered a concerning disease in Brazilian poultry industry because fowlpox vaccination is carried out in the whole poultry production during the summer.

It must be highlighted that the amplified gene fragment used in the phylogenetic analyses is short, about 580 base pairs, allowing only a preliminary classification of the virus. More consistent sequence data from additional genomic regions would be required for an elucidative taxonomic classification of the virus detected here. Further studies should be carried out to assess the potential pathogenic role of APV to other species, providing new insights into the ecology and evolution of APV in different avian species.

\section{CONCLUSIONS}

To our knowledge, this study shows the first phylogenetic analysis of APV in turkeys in Brazil. Other avian species (e.g. poultry, laying hens, wild birds, pet birds) may probably be infected by APV and leading to severe economic losses in the Brazilian poultry industry.

Additional studies with larger numbers of turkeys and other avian species, as well as the continued vigilance on the occurrence of viral infections in poultry, laying hens and turkey production is necessary to follow the evolution of APV and its interactions with the different avian host species.

The detection of APV in Brazilian turkey production nearby to another poultry production or laying hens may be a hazardous risk to the Brazilian poultry production scenario.

Our findings point to the need to identify the prevalence of APV in Brazilian turkeys, poultry and laying hens, to perform risk assessment studies and continued surveillance of APV infections in both wild and commercial avian species.

Acknowledgements.- This study was supported by grants from: Conselho Nacional de Desenvolvimento Científico e Tecnológico (CNPq) (Proc. 
458299/2012-0; 312126/2013-1; 578440/2008-3; 552584/2009-6; 314311/2009-2), Financiadora de Estudos e Projetos (FINEP) (Proc. 01100783.00), and Fundação de Amparo à Pesquisa do Estado do Rio Grande do Sul (FAPERGS) (1066-2551/13-0).

Author disclosure statement.- The authors state that no competing financial interests exist.

\section{Authors' contributions:}

1) Hiran Castagnino Kunert Filho $\rightarrow$ Wrote the paper, performed the experiments (PCR standardization, phylogenetic analysis);

2) Samuel Paulo Cibulski $\rightarrow$ Wrote the paper, performed the experiments

(Phylogenetic analysis, phylogenetic tree draw);

3) Fabrine Finkler $\rightarrow$ Necropsy, Sample collect, DNA extraction;

4) Tiela Trapp Grassotti $\rightarrow$ Necropsy, sample collect, DNA extraction;

5) Fátima Regina Ferreira Jaenisch $\rightarrow$ Conceived the experiments, histological analysis;

6) Kelly Cristina Tagliari de Brito $\rightarrow$ Conceived the experiments, correction;

7) Daiane Carvalho $\rightarrow$ Sample collect, necropsy, DNA extraction;

8) Maristela Lovato $\rightarrow$ Conceived the experiments, correction;

9) Benito Guimarães de Brito $\rightarrow$ Conceived the experiments, correction.

\section{REFERENCES}

Back A., Soncini R.A., Ruthes O., Madureira Jr S. \& Flores R. 1995. An Atypical fowl pox outbreak in broilers in Southern Brazil. Avian. Dis. 39(4):902-906.

Binns M.M., Boursnell M.E.G., Tomley F.M. \& Campbell J. 1989. Analysis of the Fowlpox virus gene encoding the $4 \mathrm{~b}$ core polypeptide and demonstration that it possesses efficient promoter sequences. Virol. 170(1):288-291.

Biswas S.K., Jana C., Chand K., Rehman W. \& Mondal B. 2011. Detection of fowl poxvirus integrated with reticuloendotheliosis virus sequences from an outbreak in backyard chickens in India. Vet. Ital. 47(2):147-153.

Bolte A.L., Meurer J. \& Kaleta E.F. 1999. Avian host spectrum of avipoxviruses. Avian Pathol. 28(5):415-432.

Fallavena L.C., Canal C.W., Salle C.T., Moraes H.L., Rocha S.L., Pereira R.A. \& da Silva A.B. 2002. Presence of avianpoxvirus DNA in avian dermal squamous cell carcinoma. Avian Pathol. 31(3):241-246.

Fletcher O.J. 2008. Avian Histopathology. 3rd ed. North Carolina: American Association of Avian Pathologist.

Godoy L.A., Dalbeck L.S., Tell L.A., Woods L.W., Colwell R.R., Robinson B., Wethington S.M., Moresco A., Woolcock P.R. \& Ernest HB. 2013. Characterization of avian poxvirus in Anna's Hummingbird (Calypte anna) in California, USA. J. Wildl. Dis. 49(4):978-985.

Gubser C., Hué S., Kellam P. \& Smith G.L. 2004. Poxvirus genomes: a phylogenetic analysis. J. Gen. Virol. 85(Pt 1):105-117.

Ha H.J., Howe L., Alley M. \& Gartrell B. 2011. The phylogenetic analysis of avipoxvirus in New Zealand. Vet. Microbiol. 150(1/2):80-87.

Hughes A.L., Irausquin S. \& Friedman R. 2010. The evolutionary biology of poxviruses. Infect. Genet. Evol. 10(1):50-59.

Huw Lee L. \& Hwa Lee K. 1997. Application of the polymerase chain reaction for the diagnosis of fowl poxvirus infection. J. Virol. Methods 63(1/2):113-119.

Jarmin S., Manvell R., Gough R.E., Laidlaw S.M. \& Skinner M.A. 2006.
Avipoxvirus phylogenetics: identification of a PCR length polymorphism that discriminates between the two major clades. J. Gen. Virol. 87(Pt 8): 2191-2201.

Kim T.J., Schnitzlein W.M., McAloose D., Pessier A.P. \& Tripathy D.N. 2003. Characterization of an avianpox virus isolated from an Andean condor (Vultur gryphus). Vet. Microbiol. 96(3):237-246.

Lamounier R.D., Carvalho F.V., Netto A.R. \& Corbett C.E. 1966. Tratamento da forma epiteliomatosa da bouba aviária em perus (Meleagris gallopavo) pelo diaceturado do di-(4-aminodifenil)-(n-1,3)-triazeno. Revta Fac. Med. Vet. São Paulo 7(3):745-753.

Lefkowitz E.J., Wang C. \& Upton C. 2006. Poxviruses: past, present, and future. Virus Res. 117:105-118.

Luna L.G. 1968. Manual of histologic staining methods of the Armed Forces Institute of Pathology. 3rd ed. McGraw-Hill, New York.

Lüschow D., Hoffmann T. \& Hafez H.M. 2004. Differentiation of avian poxvirus strains on the basis of nucleotide sequences of $4 \mathrm{~b}$ gene fragment. Avian Dis. 48(3):453-462.

Manarolla G., Pisoni G., Sironi G. \& Rampin T. 2010. Molecular biological characterization of avian poxvirus strains isolated from different avian species. Vet. Microbiol. 140(1/2):1-8.

Pereira W.L.A., Gabriel A.L.M., Monger S.G.B., Moraes L.A., Queiroz D.K.S. \& Souza A.J.S. 2014. Lesões cutâneas tipo tumorais associadas à infecção por Avipoxvirus em uma marreca-cabocla (Dendrocygna autumnalis). Ciênc. Anim. Bras. 15(2):234-238.

Sambrook J. \& Russel D.W. 2001. Rapid isolation of yeast DNA, p.6.31-6.32. Protocol 7. In: Sambrook J. \& Russel D.W. (Eds), Molecular Cloning: a laboratory manual. Vol.1. Cold Spring Harbor Laboratory, New York.

Silva P.S., Batinga T.B., Sales T.S., Herval E.F.G., Ramos I., Maia P.C.C. \& Fernandes L.M.B. 2009. Fowlpox: Identification and adoption of prophylactic measures in backyard chickens in Bahia, Brazil. Braz. J. Poult. Sci. 11(2):115-119

Tadese T., Fitzgerald S. \& Reed W.M. 2008. Detection and differentiation of re-emerging fowlpox virus (FWPV) strains carrying integrated reticuloendotheliosis virus (FWPV-REV) by real-time PCR. Vet. Microbiol. 127(1/2):39-49.

Vargas G.D., Albano A.P., Fischer G., Hübner S., Sallis S.E., Nunes C.F., Raffi M.B. \& Soares M.P. 2011. Avian pox virus infection in a common barn owl (Tyto alba) in southern Brazil. Pesq. Vet. Bras. 31(7):620-622.

Tamura K., Stecher G., Peterson D., Filipski A. \& Kumar S. 2013. MEGA 6: Molecular Evolutionary Genetics Analysis Version 6.0. Mol. Biol. Evol. 30(12):2725-2729.

Thompson J.D., Higgins D.G. \& Gibson T.J. 1994. CLUSTAL W: improving the sensitivity of progressive multiple sequence alignment through sequence weighting, position-specific gap penalties and weight matrix choice. Nucleic Acids Res. 22(22):4673-4680.

Tripathy D.N. \& Reed W.M. 2013. Pox, p.333-349. In: Swayne D.E. (Ed.), Disease of Poultry. 13th ed. Willey-Blackwell Press, Ames.

Tripathy D.N., Schnitzlein W.M., Morris P.J., Janssen D.L., Zuba J.K., Massey G. \& Atkinson C.T. 2000. Characterization of poxviruses from forest birds in Hawaii. J. Wildl. Dis. 36(2):225-230.

Weli S.C., Traavik T., Tryland M., Coucheron D.H. \& Nilssen $\emptyset .2004$. Analysis and comparison of the $4 \mathrm{~b}$ core protein gene of avipoxviruses from wild birds: evidence for interspecies spatial phylogenetic variation. Arch. Virol. 149(10):2035-2046. 